\title{
Financial Environment, City Distance and International Operation of Chinese Enterprises
}

\author{
Chuan $\operatorname{Lin}^{1} \&$ Jingjing Luo ${ }^{1}$ \\ ${ }^{1}$ Research Center for International Business and Economy, Sichuan International Studies University, Chongqing, \\ China \\ Correspondence: Jingjing Luo, Research Center for International Business and Economy, Sichuan International \\ Studies University, Chongqing 40031, China.
}

Received: October 18, 2018

Accepted: November 12, 2018

Online Published: November 22, 2018

doi:10.5430/ijba.v9n6p61

URL: https://doi.org/10.5430/ijba.v9n6p61

\begin{abstract}
This paper uses the 9741 internationally-operated Chinese companies and their matched companies in Shanghai and Shenzhen A-shares as a sample to empirically examine the relationship between financial environment, distance and international operation. First of all, the study found that there is a significant positive correlation between the financial environment and the international operation of the company. In other words, the better the financial environment in which the company is located, the more likely it is that the company will conduct international operations. Second, there is also a significant positive correlation between distances and international operations, which means that the closer the geographical location of the registered place of a company and the central city of the province, the more likely it is that the enterprises within the jurisdiction are operating internationally. Furthermore, the urban distance can produce a 'regulatory effect' between the financial environment and the international operation of the enterprise. That is the positive correlation between the financial environment and the international operation of the enterprise depends on the 'city distance'. Considering the influence of 'city distance', the positive impact of the financial environment on international operations is even more pronounced.
\end{abstract}

Keywords: international operation, financial environment, city distance, Chinese enterprises

\section{Introduction}

Diversification is a model in which after a certain stage of development, the company chooses another way to expand its business scope and obtain new economic growth points. The traditional diversified economic model mostly refers to industry diversification that is another related or unrelated industry outside the main business operations of the enterprise. However, due to the diversification of the industry, companies often need to invest more manpower, material resources and financial resources, so that although diversified operations in the industry can reduce the risk of the enterprise, it will also become a cost for the company's operations, not necessarily bringing premiums to companies (Mansi and Reeb, 2002). Therefore, the issue of diversification has become a problem that has plagued the academic and practical world (Villalonga, 2004; Wei and Sun, 2008; Sun and Huang, 2013). Nevertheless, with the gradual increase of the degree of openness of the world economy and the gradual elimination of international trade barriers, more companies have begun to expand the geographical scope of their operations and have gradually increased their international business strategy to a very important position, especially this phenomenon not only occurs in developed countries, but also in companies in emerging market economies. In contrast to industry diversification, in the process of international operation of a company, although problems such as cultural conflicts are also encountered, it is not necessary to get involved in an industry that may be completely unfamiliar. Then compared with the huge actual cost and opportunity cost in the industry diversification, the company only needs to pay sales cost and management cost in the international diversified new market, especially in the early stage of international diversification, enterprises only need to pay sales costs and management costs, while the opportunity cost of using core technologies is close to zero, which will enable the company to achieve faster growth (Sun and Huang, 2013). Therefore, under the current background of global economic integration, it is very important to discuss how companies can obtain new economic growth points through internationally diversified management channels and further expand internationalization. 
However, unlike the diversification of the industry, there are few international operation concerns (Sun and Huang, 2013). Most studies have focused on whether companies can improve their business performance or reduce their financial risk through international operations (Kim et al., 1989; Duru and Reeb, 2002; Buckley and Casson, 2009). But it is rarely involved in the factors that lead companies to choose the strategy of international operation, and this is the issue that the practice community is most concerned about (Dai et al., 2016). At present, in the theoretical explanation of the diversification of enterprises, on the one hand, it is based on the explanations of the internal agency theories and resource-based theories. On the other hand, from the interpretation of the market environment and the basic theory of the system, it is based on the external environment in which the company is located. Nevertheless, compared with the internal motivation, the international operation is an cross-regional business operation. So the development of the external market environment will inevitably have a great impact. It will not only produce corresponding external governance effects, but will also have an important dependence on the internal development of the company. Especially for Chinese companies that are still in the weak legal environment in the context of emerging markets and transition economies, coupled with the huge land area and uneven development status between provinces and cities, so it is of great theoretical significance to study international operations based on the perspective of the external financial market environment.

Therefore, this paper uses the internationally-operated companies and their counterparts in China's Shanghai and Shenzhen A-share listed companies during the period of 2008-2016 as samples. Based on the external perspectives of business operations, the impact of the financial environment of the city in which the company is registered on the micro-international operating behavior of the company is discussed, and the distance between the registered location of the company and the central city is taken into consideration. Different from existing literature, on the one hand, based on an external perspective, this paper considers the various factors that can be provided by the financial environment of a company's place of registration for the company's international operations. While the existing literature more considers that the micro-behavior of the enterprise stems from the internal factors of the enterprise. On the other hand, this paper considers whether the 'city distance' advantage formed by the geographical location of the company conveys the 'soft information' transmitted by external factors in the course of business operations, and thus has an impact on the international operation of the company. This is also a problem that has not been concerned in the existing literature.

\section{Theoretical Analyses}

\subsection{Financial Environment and International Operation}

Starting from La Porta et al. (2000), the impact of the external governance environment on the internal governance structure of listed companies and the long-term development of the company has gradually begun to be noticed, especially in the external financial environment. A good external financial environment can give enterprises more room for development, reduce the unregulated financial vicious competition in the region where the company is located, and thus safeguards the legitimate rights and interests of corporate shareholders and strengthens the ability of the company to resist external risks and even the entire financial market to withstand the crisis (Johnson et al., 2000).In general, differences in the external financial environment are mainly reflected in different financial systems among different countries, and usually within a country, because all companies will face the same financial system, so there will be no big difference. However, in China, on the one hand, due to the large geographical scope, the natural conditions and economic foundations of different provinces are very different. As a result, the financial environment faced by companies in different provinces in the early stages of development has been different. On the other hand, from the perspective of the current development situation since China's reform and opening up, although it has been pursuing common development, it is unavoidable that due to differences in development time, policy preferences and differences in natural conditions, the eastern coastal areas have developed faster than inland areas. Therefore, in the Chinese capital market, the investment environment and financial competition faced by companies in different regions actually differ greatly. In fact, in China's capital market, the number, size, structure and operating efficiency of companies in different provinces and cities are very different (Zhong, 2002). Similarly, although China's foreign trade and foreign investment have developed rapidly in recent years, the distribution of sources within the provinces is also very different. From the perspective of non-financial OFDI traffic distribution in different regions in late 2001, the eastern region occupies $72.83 \%$, central and west account for only $15.46 \%$ and $11.71 \%$, respectively (Chen, 2014).

Therefore, this paper refers to the classical model established by La Porta et al.(2000) in law and economics, and discusses the influence of the financial environment on the choice of international operations. First of all, this paper presents the corresponding research hypothesis: 
Hypothesis 1: The company has an opportunity to conduct international operations. Its investment amount is $I$. Without considering the financing cost, the investment return rate of the international operation is $r$.

Hypothesis 2: There is a controlling shareholder in the company. Its shareholding ratio is $\alpha, \alpha$ is exogenous, and the controlling shareholder will use its own advantage to gain private interests. Then the encroachment behavior is $s$, and the encroachment behavior will reduce the company's internationalization income.

Hypothesis 3: The controlling shareholder's encroachment behavior will be constrained by the external institutional environment. It means that the governance effect of the financial environment is defined as $\mathrm{k}$, so the cost function for the controlling shareholder to obtain private interest is $c(k, s)=\left(k s^{2}\right) / 2$, and $c_{k}>0, c_{s}>0, c_{s s}>0, c_{k s}>0$.

Hypothesis 4: In Chinese companies, there are differences between state-owned and non-state-owned enterprises. Therefore, in different types of enterprises, there is a difference between the infringement willingness and the expropriation ability of the controlling shareholder. So the enterprise attribute is defined as $m$.

Therefore, according to the definition of La Porta et al. (2000), when a company chooses to operate internationally, the largest gains the company's controlling shareholders can obtain are:

$$
T R=s m R I-\frac{1}{2} k s^{2} R I+\alpha(1-s) R I
$$

Then, find the first-order partial derivative of $s$ with respect to (1), and make it equal to 0 , so as to obtain the optimal encroachment level of controlling shareholders:

$$
s^{*}=\frac{1}{k}(m-\alpha)
$$

At the same time, by discussing $k$ in (2), we can get:

$$
c_{k s}(k, s)+c_{s s}(k, s) \frac{d s^{*}}{d k}=0, \frac{d s^{*}}{d k}=-\frac{c_{k s}(k, s)}{c_{s s}(k, s)}<0
$$

From the formula (3), we can see that with the increase of the external financial environment, the degree of infringement of the controlling shareholder on the company will be reduced, so that the company's internationalization gains may increase. Thus, referring to the method of La Porta et al.(2000), $q$ is defined as the value of the enterprise participating in the international operation, namely $q=\left(1-s^{*}\right) R$, and the collation result can be obtained:

$$
\frac{d q}{d k}=-\frac{d s^{*}}{d k} R>0 、 \frac{d q}{d \alpha}=-\frac{d s^{*}}{d \alpha} R>0, \quad \frac{d q}{d R}>0
$$

From formula (4), it can be seen that the better the external financial environment, the higher the company's income from international operations. Therefore, put forward the first hypothesis to be tested in this paper:

H1: There is a positive correlation between the financial environment and the international operation of the company. In other words, the better the financial environment of the company's region, the higher the probability of conducting international operations.

\subsection{Financial Environment, Distance and International Operation}

In recent years, with the rise and development of new economic geography, the economic relationship formed by the geographic location of the city and the geographical distance between cities has attracted more and more attention of scholars. Krugman (1993) put forward the concept of 'natural elements' and pointed out those important economic resources such as raw materials, energy, land, etc., are mostly controlled by cities or regions that are closer to the central city. In short, compared to cities farther from the central city and cities relatively close to the central city, on the one hand they may have more abundant resources on their own. And on the other hand, the operating costs of enterprises within their jurisdictions will be lower and it will reduce the overall cost of the company's international operations.

Therefore, in actual business activities, companies will select their own registered sites according to the regional advantage theory. That is the closer the distance to the central city is, the more companies may flow into the region 
(Dunnning, 1998). In other words, the distance between the city and the center city forms a central system where the company can grasp resources. Meanwhile, it also has an impact on the company's agency costs, information asymmetry, etc., which in turn affects the performance of the company (Kalnins and Lafontaine, 2013; Huang et al., 2016). It can be seen that the closer the distance from the central city is, the stronger the financial environment that can be obtained provides superiority, so that enterprises within the jurisdiction can obtain more effective financial information advantages, and can obtain more valuable internationalized resources and information (Lerner, 1995; Coval and Moskowitz, 2001; Ivkoviè and Weisbenner, 2005). What's more, it can provide a broader development platform, a better financing environment, more adequate funding and more convenient financing conditions for the company's international operations, which is more conducive to promoting international operations. Therefore, the second hypothesis to be tested in this paper is:

$\mathrm{H} 2$ : The distance can produce a 'regulatory effect' between the financial environment and the international operation of the enterprise.

\section{Empirical Methodology}

\subsection{Variable Interpretation}

(1) International Operation (IO): Considering that many Chinese listed companies disclose their overseas income, they do not have the same statistical coverage for overseas regions. Therefore, this paper chooses a dummy variable to measure the international operation whether the company has overseas income: if the company has offshore income, then $I O=1$, otherwise $I O=0$.

(2) Financial Environment $(F E)$ : This paper measures the financial environmental indices of provinces provided by Wang et al. (2018) in the 'Business Environment Index for China's Provinces 2017 Report'.

(3) City Distance $(C D)$ : This paper measures the shortest distance between the city where the sample company is registered and the capital city of the province (or municipality directly under the jurisdiction of the center, in which the central area of Beijing is defined as Dongcheng District, the central area of Shanghai is defined as Huangpu District, the central area of Tianjin is defined as Heping District, and the central area of Chongqing is defined as Yuzhong District). According to the measured distance, if the distance is $(0,1) \mathrm{km}$, then $C D=6$; if the distance is $[1,200) \mathrm{km}$, then $C D=5$; if the distance is $[200,400) \mathrm{km}$, then $C D=4$; If the distance is $[400,600] \mathrm{km}$, then $C D=3$; if the distance is $[600,800) \mathrm{km}$, then $C D=2$; if the distance is $[800,1000) \mathrm{km}$, then $C D=1$; if the distance is greater than $1000 \mathrm{~km}$, Then $C D=0$. The larger the value of the variable $C D$, the closer the company is registered to the center of the province.

(4) Control Variable: Referring to the existing literature, this article adds asset size (Size), return on assets (ROA), asset-liability ratio (Debt), and ownership concentration (H10) as control variables. At the same time, it controls the Indu and Year factors of the sample companies.

Asset Size (Size): Measured by the total assets of the sample enterprise, and take the natural logarithm;

Return on Assets (ROA): Measured by the ratio of net profit to total assets of the sample enterprise;

Asset-liability Ratio (Debt): Measured by the ratio of total liabilities to total assets of the sample enterprise;

Ownership Concentration (H10): Measured by the square sum of the top ten shareholders of the sample enterprise.

\subsection{Empirical Model}

According to the previous study design, and in order to test the impact of the financial environment on international operations, this paper constructs the empirical model:

$$
\operatorname{logit}(I O)=\alpha_{1} F E+\alpha_{2} \ln (\text { Size })+\alpha_{3} R O A+\alpha_{4} D e b t++\alpha_{5} H 10+\text { Indu }+ \text { Year }+C+\varepsilon
$$

At the same time, in order to test the regulatory effect of urban distance, an empirical model is constructed to:

$$
\operatorname{logit}(I O)=\left(\begin{array}{l}
\alpha_{1} F E+\alpha_{2} C D+\alpha_{3}(F E \times C D)+\alpha_{4} \ln (\text { Size })+\alpha_{5} R O A+\alpha_{6} D e b t \\
+\alpha_{7} H 10+\text { Indu }+ \text { Year }+C+\varepsilon
\end{array}\right)
$$




\subsection{Sampling and Data Sources}

This paper uses the company with overseas operating income as the original sample in the financial reports of China's Shanghai and Shenzhen A-share listed companies during the period of 2008-2016. According to the following principles, the sample was removed. First, the samples of listed companies in the financial and insurance industries were excluded. Second, samples of special processing companies were excluded. Third, samples of companies listed on the GEM were excluded. Fourth, samples of IPO listed companies were excluded. Moreover, samples of missing data or singular data were excluded. At the same time, in order to better contrast with international operating companies, this paper chooses to pair the sample of international operating companies. The principles of pairing are as follows: first of all, they belong to the same industry as international operating companies. Secondly, they belong to non-GEM listed companies. Thirdly, it belongs to a non-special number of companies. In addition, it is the closest to the total assets of international operating companies, but the difference in total assets does not exceed $50 \%$ of them. After excluding the duplicated samples, this paper eventually obtained 9741 samples from 2008-2016.

The international business data, financial data and governance data of the sample companies are derived from the SINOFIN economic database. The company registration data is from the RESSET financial database, and the corporate distance data was measured by Gore map software and corrected by Baidu map software.

\section{Empirical Results and Analysis}

\subsection{Descriptive Statistics}

Table 1. Descriptive statistics

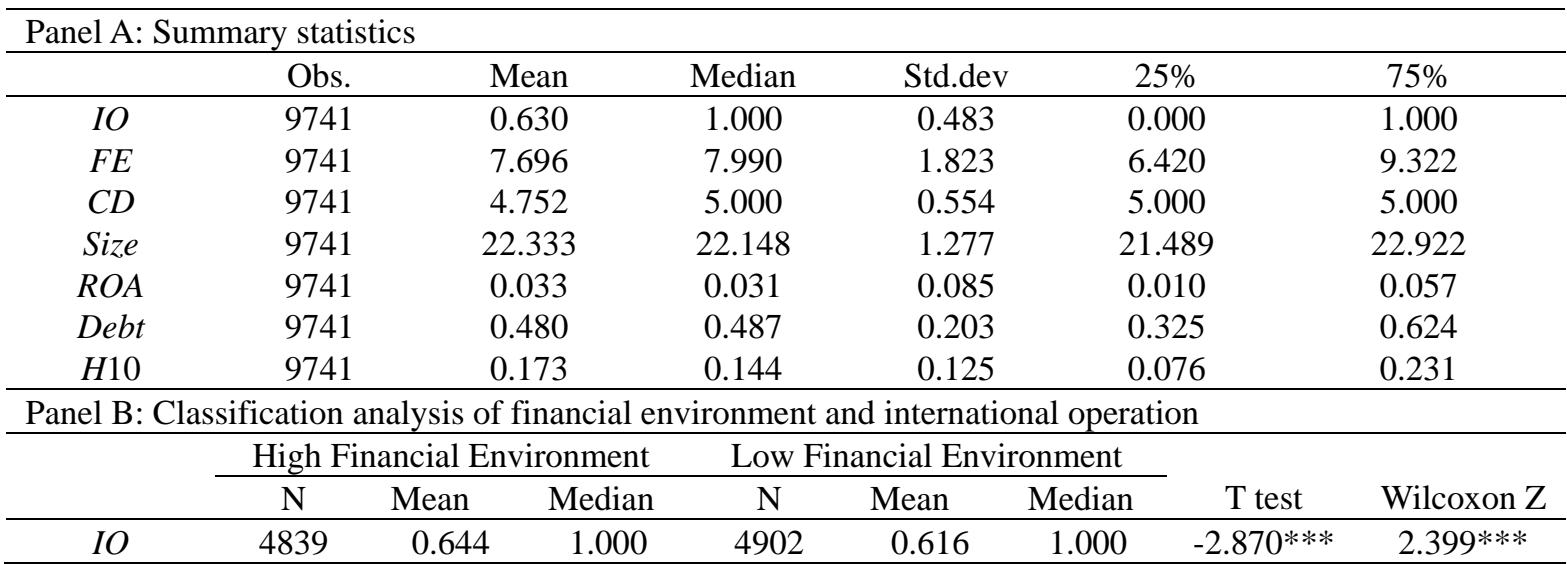

Note: *,**, and *** indicate statistical significance at the $10 \%, 5 \%$, and $1 \%$ levels, respectively.

From the results of Panel A of Table1, first of all, the mean value of the $I O$ of the explanatory variable is 0.630 , which indicates that about two-thirds of the Chinese enterprises have conducted international operations in this sample, and the remaining one third of the enterprises still choose simplified domestic operations. Second, the median of explanatory variable $F E$ is 7.99 , but the external financial environment faced by different Chinese companies is quite different. Furthermore, the explanatory variable $C D$ has a value of 5 , indicating that most sample companies set the distance to the central city to be around $200 \mathrm{~km}$, which may better maintain the geographical distance to the central city, thereby reducing the cost of the company's international operations.

In addition, from Table 1's Panel B results, the mean value of variable $I O$ in the high financial environment group is 0.644 , while the mean value of variable $I O$ in the low financial environment group is 0.616 , which indicates that in the high financial environment group, the number of companies that choose to operate internationally is more, and this difference can pass the significant test of the level of conventional confidence. 


\subsection{Multivariate Analyses}

Table 2. Multiple regression results

\begin{tabular}{cccccc}
\hline & $(1)$ & $(2)$ & $(3)$ & $(4)$ & $(5)$ \\
\hline FE & $0.033^{* * *}$ & & $0.062^{* * *}$ & & $0.237^{* * *}$ \\
& $(0.011)$ & & $(0.013)$ & & $(0.090)$ \\
CD & & $0.150^{* * *}$ & & $0.165^{* * * *}$ & $0.410^{* * *}$ \\
& & $(0.037)$ & & $(0.039)$ & $(0.135)$ \\
FE*CD & & & & $-0.038^{* *}$ \\
Size & & & $0.200^{* * *}$ & $0.200^{* * * *}$ & $(0.019)$ \\
ROA & & & $-1.868^{* * *}$ & $-1.766^{* * *}$ & $-1.871^{* * * *}$ \\
Debt & & & $0.740^{* * *}$ & $0.678^{* * * *}$ & $0.727^{* * *}$ \\
H10 & & & $-0.869^{* * *}$ & $-0.893^{* * *}$ & $-0.892^{* * *}$ \\
Indu & Yes & Yes & Yes & Yes & Yes \\
Year & Yes & Yes & Yes & Yes & Yes \\
Constant & $0.282^{* * *}$ & -0.181 & $-4.249^{* * *}$ & $-4.557^{* * *}$ & $-6.148^{* * *}$ \\
Mc Fadden R ${ }^{2}$ & 0.001 & 0.002 & 0.041 & 0.041 & 0.042 \\
LR Statistic & $8.090^{* * *}$ & $16.173^{* * *}$ & $525.720^{* * *}$ & $520.544 * * *$ & $544.576^{* * *}$ \\
\hline
\end{tabular}

Note: The standard error reported in parentheses. $*$, **, and $* * *$ indicate statistical significance at the $10 \%, 5 \%$, and $1 \%$ levels, respectively.

Table 2 presents the multiple regression test results of the financial environment, distance, and international operations. From the overall regression statistics of the regression results, both can pass the significance test of the conventional confidence level, indicating that there is no substantial difference between the actual distribution of the explained variables and the predicted distribution fitted by the explanatory variables and control variables. Then from the specific regression results, when the regression result (1) only controls the industry and annual effects, there is a significant positive correlation between the explanatory variable $F E$ and the explanatory variable $I O$. After controlling the corresponding control variables, the regression result (3) shows that there is still a positive correlation between the explanatory variable $\mathrm{FE}$ and the explanatory variable $I O$, and all of them can pass the significant test of the conventional confidence level. It shows that, first of all, compared to the poor external financial environment in the region, the better the external financial environment, the more likely it is that the company will conduct international operations. In other words, the financial environment has promoted the international operations and provided support and motivation for companies to carry out internationalization activities. This result validates the previous research $\mathrm{H} 1$.

Consider the effect of adding the variable $C D$ to the effect of the explanatory variable $F E$ on the explanatory variable $I O$. In the regression result (5), the coefficient value of the variable $F E$ remains positive and still passes the significance test of the conventional confidence level. Comparing the regression result (5) with the regression result (3), it is found that the coefficient value of the variable FE is significantly higher, indicating that after the consideration of the distance is added, the impact of the financial environment on international operations is even more pronounced. It can be seen that the relationship between the financial environment and internationalized operations will be affected by the distance of the cities. That is, the closer the geographical distance to the provincial administrative center, the more financially stimulating the financial environment can promote international operations. This verifies the previous research $\mathrm{H} 2$.

From the regression results of the control variables, on the one hand, there is a significant positive correlation between the explanatory variables Size, Debt and the explanatory variable $I O$. This indicates that the higher the asset size of the company, the higher the debt ratio, and the more likely it is to conduct international operations. On the other hand, there is a significant negative correlation between the explanatory variables ROA, $H 10$ and the explanatory variable $I O$, indicating that the higher the capital yield and the lower the degree of ownership concentration, the higher the probability of international operation.

In order to verify the robustness of the previous research results, the corresponding robustness test is performed in this paper. Firstly, the ridge regression test is performed in consideration of the strong correlation between the 
variables generated by the interaction factors. Secondly, considering that the sample includes enterprises in Beijing, Shanghai, Tianjin and Chongqing, four municipalities directly under the Central Government, the administrative level of these companies' registered locations is significantly different from that of the corporate cities. Therefore, after the sample of enterprises registered in these four municipalities is excluded, a regression test is conducted. There is no substantial difference between the results of the robustness test and the previous empirical results, so it can be concluded that the conclusions of this paper are reliable

\section{Conclusion}

International operation is a business model in which the company further expands its business space in the course of business operations and sells products in different countries or regions. In recent years, with the continuous expansion of China's opening up pattern and the continuous implementation of the 'going out' strategy, Chinese companies have increasingly used overseas markets for sales and investment, and their international operations have also deepened. So this paper takes 9741 international and A-share listed companies in the Shanghai and Shenzhen A-shares as a sample from 2008 to 2016, and empirically tests the relationship between the financial environment, distance, and international operations. First of all, it is found that there is a significant positive correlation between the financial environment and the international operation of the company, which means that the better the financial environment in which the company is located, the more likely it is that the company will operate internationally. Second, the urban distance can produce a 'regulatory effect' between the financial environment and the international operation of the enterprise. That is, the positive correlation between the financial environment and the international operation of the enterprise depends on the 'city distance'. Furthermore, considering the influence of 'city distance', the positive impact of the financial environment on international operations is even more pronounced.

Judging from the empirical evidence in this paper, external factors have had a significant impact on the micro-firm's behavior, which means that it provides a good external environment for the enterprise and is more conducive to the company's international operations. First of all, from the perspective of the government, on the one hand, the state should introduce or improve relevant laws and regulations to provide legal support and legal guarantees for enterprises to conduct international operations. At the same time, tough sanctions should also be imposed on companies' bad behavior to ensure the rationality and legitimacy of international operations. On the other hand, it should change government functions, realize the transition from an administrative government to a service-oriented government, increase the transparency of policies, simplify government approval procedures, and provide standardized services for enterprises to 'going out' and carry out international operations. Meanwhile, from the perspective of the enterprise, enterprises should seize opportunities in a timely manner to adjust their own industrial structure and business strategy. Then they must also take into account the development of the domestic market and eliminate the 'worry for the future' for international operations. In addition, when undertaking international operations, companies should also follow the laws and regulations of the 'host' countries or regions and at the same time, respect their customs and habits and provide a good external environment for international development.

\section{Acknowledgment}

The authors acknowledge funding from the key project Chongqing Social Science Foundation of China (Project No. 2016YBJJ029). Besides, Jingjing Luo is the corresponding author and can be contacted at: 631077294@qq.com.

\section{References}

Buckley, P.J., \& Casson, M.C. (2009). The Internalization Theory of the Multinational Enterprise: A Review of the Progress of a Research Agenda after 30 Years. Journal of International Business Studies, 40(9), 1563-1580. https://doi.org/10.1057/jibs.2009.49

Chen, J.H. (2014). Regional Difference Decomposition and Influence Factors of China's OFDI. The Journal of Quantitative \& Technical Economics, 31(7), 21-37.

Coval, J.D., \& Moskowitz, J.T. (2001). The Geography of Investment: Informed Trading and Asset Prices. Journal of Political Economy, 109(4), 811-841. https://doi.org/10.1086/322088

Dai, B., Yang, B., \& Peng, C. (2016). Shareholders' Resources, Power of CEOs and Internationalization Strategy of Enterprises: A Study Based on the Empirical Evidence from Listed. International Business, 40(3), 116-128.

Dunning, J.H. (1998). Location and the Multinational Enterprise: A Neglected Factor. Journal of International Business Studies, 29(1), 29-61. https://doi.org/10.1057/palgrave.jibs.8490024

Duru, A., \& Reeb, D.M. (2002). International Diversification and Analysts' Forecast Accuracy and Bias. The Accounting Review, 77(2), 415-433. https://doi.org/10.2308/accr.2002.77.2.415 
Huang, Z.K., Liu, J.Y., \& Ma, G.R. (2016). Geographic Location, China Railways High-speed and Information: Evidence from China's IPO Market. The Journal of World Economy, 39(10), 127-149.

Ivkoviè, Z., \& Weisbenner, S. (2005). Local Does as Local is: Information Content of the Geography of Individual Investors' Common Stock Investments. Journal of Finance, 60(1), 267-306. https://doi.org/10.1111/j.1540-6261.2005.00730.x

Johnson, S., La Porta, R., Lopez-de-Silanes, F., \& Shleifer, A. (2000). Tunneling. American Economic Review, 90(2), 22-27. https://doi.org/10.1257/aer.90.2.22

Kalnins, A., \& Lafontaine, F. (2013). Too Far Away? The Effect of Distance to Headquarters on Business Establishment Performance. The American Economic Journal: Microeconomics, 5(3), 157-179. https://doi.org/10.1257/mic.5.3.157

Kim, W., Hwang, P., \& Burger, W. (1989). Global Diversification Strategy and Corporate Profit Performance. Strategic Management Journal, 10(1), 45-57. https://doi.org/10.1002/smj.4250100105

Krugman, P. (1993). On the Number and Location of Cities. European Economic Review, 37(2), 293-298. https://doi.org/10.1016/0014-2921(93)90017-5

La porta, R., Lopez-de-Silanes, F., Shleifer, A., \& Vishny, R. (2000). Agency Problems and Dividend Policies around the World. Journal of Financial Economics, 55(1), 3-27.

Lerner, J. (1995). Venture Capitalists and the Oversight of Private Firms. Journal of Finance, 50(1), 301-318. https://doi.org/10.1111/j.1540-6261.1995.tb05175.x

Mansi, S., \& Reeb, D. (2002). Corporate Diversification: What Gets Discounted. Journal of Finance, 57(5), 2167-2183. https://doi.org/10.1111/0022-1082.00492

Sun, W.F., \& Huang, Z.H. (2013). Relationship between International Diversification and Firm Performance: Empirical Evidence from Chinese Listed Corporation. Chinese Journal of Management, 10(8), 1128-1137.

Villalonga, B. (2004). Diversification Discount or Premium? New Evidence from BITS Establishment-level Data. Journal of Finance, 59(1), 479-506. https://doi.org/10.1111/j.1540-6261.2004.00640.x

Wang, X.L. (2018). Business Environment Index for China's Provinces 2017 Report. Social Sciences Academic Press (CHINA).

Wei, F., \& Sun, X.D. (2008). Diversification and Corporate Risk. Securities Market Herald, 28(6), 63-76.

Zhong, H.Y. (2002). Regional Differences between China's Listed Corporates. Journal of Southwest Institute for Ethnic Groups, 23(8), 18-25. 